\title{
Trade openness, income levels, and economic growth: The case of developing countries, 1970-2009
}

\author{
Daniel Sakyi ${ }^{\mathrm{a}}$, Jose Villaverde ${ }^{\mathrm{b}}$ and Adolfo Maza ${ }^{\mathrm{b}}$ \\ ${ }^{a}$ Department of Economics, Kwame Nkrumah University of Science and Technology \\ (KNUST), Kumasi, PMB, Ghana; ${ }^{b}$ Department of Economics, University of Cantabria, \\ 39005 Santander, Spain
}

(Received 11 March 2014; accepted 27 September 2014)

\begin{abstract}
This paper attempts to investigate the extent to which trade openness has had an impact on the levels of income and rates of growth in a sample of 115 developing countries for the period 1970-2009. Additionally, to assess whether there is an income level threshold for a country to benefit from international trade, the sample is broken down into three mutually exclusive groups of countries: low-income, lower middle-income, and upper middleincome countries. The main novelty of the paper lies on the use, on the one hand, of a new and better trade openness measure and, on the other hand, of non-stationary heterogeneous panel cointegration techniques to cope with the problem of cross-sectional dependence. The results show a positive bidirectional relationship between trade openness and income level in the long run, thus suggesting that trade openness is both a cause and a consequence of the level of income. The results for the short run, that is, the link between openness growth and economic growth, go in the same direction.
\end{abstract}

Keywords: trade openness; income levels; economic growth; heterogeneous panels; cointegration; developing countries

JEL Classifications: F10, F43, O40, C23

\section{Introduction}

A well-established strand of the literature on international trade has made clear that trade openness is fundamental in fostering economic growth in both developed and developing countries (DCs) and, thereby, in raising their income levels. There is, however, an ongoing debate on the extent to which these effects occur, mostly with relation to DCs. ${ }^{1}$

It is therefore not surprising that many recent empirical studies have been devoted to the analysis of the relationship between trade openness and economic growth/income levels (e.g. López 2005; Herzer 2013). Overall, these studies have

*Corresponding author. Email: dsakyi.cass@knust.edu.gh 
established a positive link between these variables. The strength of this association often depends, apart from the characteristics of the sample (time span, countries) under consideration, on several factors. Among these, the most relevant are: (1) the model specification and the control variables employed; (2) the estimation techniques used (time series, cross section, or panel data) and the treatment of the potential endogeneity of trade openness; and (3) the way trade openness is measured. Regarding this issue, Rodríguez and Rodrik (2001) criticised previous analyses because they consider them being plagued by methodological problems such as inappropriate measurement of trade openness and the specification of estimated models.

Within this context, the main aim of this paper is to respond to the call for more research made by Rodríguez and Rodrik (2001). To be precise, and after revising the different trade openness measures proposed in the literature and discussing their appropriateness, we focus the study on methodological issues. This is because the econometric techniques commonly used to assess the relationship between trade and growth, namely cross-sectional regressions and homogeneous panel data techniques, may produce inconsistent and biased estimates. ${ }^{2}$ These methodologies, by neglecting the problem of cross-sectional dependence that arises from unobserved common factors, shocks and/or omitted variables, often do not take into consideration the potential non-stationarity of regressors and crosscountry heterogeneity. Moreover, issues of potential endogeneity of trade openness are often not addressed in papers using conventional methodologies. For this reason, this work also copes with the problem of a potential reverse causation running from income levels to trade openness.

Accordingly, the main contribution of this paper lies on taking advantage of the recent development of non-stationary heterogeneous panel cointegration techniques to appraise the impact of trade openness on the level of income and the rate of economic growth. More specifically, the paper provides more robust results than previous research by employing the Common Correlated Effects Mean Group (CCEMG) estimator, developed by Pesaran (2006), and the Group Mean estimators - the Fully Modified Ordinary Least Squares (FMOLS) and the Dynamic Ordinary Least Squares (DOLS) - developed by Pedroni (2000, 2001). Non-stationary heterogeneous panel cointegration estimators, such as those mentioned before, are robust to the problems associated with cross-sectional and homogeneous panel studies, namely slope heterogeneity, endogeneity regressors, and omitted variables (see Pedroni 2007; Coe, Helpman, and Hoffmaister 2009; Herzer 2013).

To this end, we use a sample of 115 DCs over the period 1970-2009 as our case study. In addition, we split the sample into three subsamples according to their relative income level. ${ }^{3}$ The reason for doing so is, in line with Kim and Lin (2009), Kim (2011), and Kim, Lin, and Suen (2011), although generally trade openness may have a positive effect on the income level of countries, there might be an income level threshold below which more openness would even harm the level of income. 
The rest of the paper is structured as follows. Next section provides a brief literature survey of the link between trade openness, income levels, and economic growth, as well as a review of the different trade openness measures proposed in this area. The empirical model we use as a benchmark, data employed, and estimation strategy are outlined in Section 3. Section 4 is devoted to the empirical analysis, presenting the results obtained for the long-run relationship between trade and income, as well as the short-run dynamics by addressing causality issues. Finally, Section 5 shows the implications of the study and offers some concluding remarks.

\section{Literature review}

This section is divided into two parts. The first one provides a survey of the literature on the theoretical and empirical links between trade openness and income levels/income growth, while the second part is devoted to a review of how to measure trade openness.

\subsection{Trade openness, income levels, and economic growth: a brief survey}

According to the literature, there are potential benefits for economic growth and development that can be derived from trade openness. These benefits - which run through technological progress ${ }^{4}$ and increased international and domestic competition - are made explicit by both extended standard neoclassical exogeneous and endogeneous economic growth models (see, e.g. Grossman and Helpman 1990, 1991; Rivera-Batiz and Romer 1991; Ben-David and Loewy 1998, 2000, 2003; Spilimbergo 2000; Perera-Tallo 2003). The framework for these models, although quite general, differentiates between groups of countries developed or developing, the various factors through which openness promote economic growth, and which is the group that benefits the most from trade openness.

Both extended neoclassical exogeneous and endogeneous growth models consider that growth depends on the rate of knowledge accumulation which, among many other factors, is fostered through unilateral and multilateral trade liberalisation policies and, then, trade openness. In the particular case of DCs, trade openness connects them to more advanced economies not only by allowing the former to acquire foreign exchange through exports, but also most importantly through the access to intermediate and high-tech goods via imports, which facilitate the diffusion of knowledge and technology (see Grossman and Helpman 1990, 1991; Rodrik 1999; Almeida and Fernandes 2008). Within this theoretical framework, comparative advantage is created endogeneously in research and development (R\&D) activities of firms which is crucial for the transfer of new technologies for these countries.

These, notwithstanding, trade openness could also be potentially detrimental to economic growth and income for DCs if it led them to specialise in sectors 
where R\&D activities are not the core ones (Rodrik 1999; Perera-Tallo 2003; Almeida and Fernandes 2008). This is the case because the endogeneous growth literature has been diverse enough to provide models in which trade openness can increase or decrease growth (Grossman and Helpman 1990; Romer 1990; Rivera-Batiz and Romer 1991; Yanikkaya 2003). Young (1991) and Perera-Tallo (2003), for example, have shown that, although trade openness may affect the level of income positively, the impact on economic growth might be negative or, if positive, not necessarily robust. This potentially low or even negative growth effect of trade openness for DCs could be explained by the existence of an income threshold below which more openness hinders the growth prospects of these countries, basically due to their human capital constraints and inability to take full advantage of international technology transfers (Kim and Lin 2009; Kim 2011). Kali, Méndez, and Reyes (2007), however, attribute this effect to the structure of international trade in DCs and argue that it not only matters to a country how large its volume of trade is, but also the number of trading partners that is able to benefit from and the type of goods (capital intensive, manufactured, or primary products) it actually trades.

Bearing these considerations in mind, it is not surprising that empirical evidence on the impact of openness on income and economic growth still remains mixed and inconclusive. ${ }^{5}$ While most recent empirical studies provide support for a positive link (e.g. Vamvakidis 2002; Irwin and Tervio 2002; Brunner 2003; Lee, Ricci, and Rigobon 2004; Alcalá and Ciccone 2004; Noguer and Siscart 2005; Salinas and Aksoy 2006; Rassekh 2007; Freund and Bolaky 2008; Wacziarg and Welch 2008; Chang, Kaltani, and Loayza 2009; Dufrénot, Mignon, and Tsangarides 2010; Squalli and Wilson 2011; Sakyi et al. 2012), a few others cast doubts about it, specifically for the developing world (see Dowrick and Golley 2004; Kim and Lin 2009; Kim 2011; Kim, Lin, and Suen 2011). In particular, Kim, Lin, and Suen (2011) have shown that international trade openness benefits rich countries more than the poor ones due to the inability of the latter to exploit knowledge accumulation and technology spillovers. All in all, these arguments suggest that not all countries take equal or similar advantage from openness, and that the income level already attained by a country and the structure of its trade seem to be key elements in trade openness to have a larger or smaller impact on income and economic growth of the country.

\subsection{Trade openness measurement issues}

We have noted in Section 1 that one of the key issues confronting empirical research on trade openness is how to measure it precisely. There exists, in fact, a vast and expanding literature on this topic to the point that trade openness has been defined in many different ways (e.g. Sachs and Warner 1995; Harrison 1996; Alcalá and Ciccone 2004; Rodrik, Subramanian, and Trebbi 2004; Ferrieri 2006; Estrada and Yap 2006; De Lombaerde 2009; Squalli and Wilson 2011). 
Existing openness measures can broadly be classified into two groups: nontrade shares (Non-TS) and trade shares (TS) based measures. Non-TS-based measures include, among others, the following: the use of the arbitrary binary $(1,0)$ measure or the Sachs and Warner index (see Sachs and Warner 1995; Greenaway, Morgan, and Wright 1998; Wacziarg and Welch 2008), the black market exchange rate premium (Sachs and Warner 1995; Harrison 1996; Rodríguez and Rodrik 2001; Vamvakidis 2002; Lee, Ricci, and Rigobon 2004), the aggregation of tariff and non-tariff barriers (Harrison 1996; Dollar and Kraay 2003), and international trade taxes (Yanikkaya 2003; Lee, Ricci, and Rigobon 2004). On the other side, TS-based openness measures refer either to the export share in GDP $(X / G D P)$, the import share in GDP $(M / G D P)$, or the share of total trade in GDP $((X+M) / G D P)$ (Harrison 1996; Irwin and Tervio 2002; Yanikkaya 2003; Lee, Ricci, and Rigobon 2004; Kim and Lin 2009; Kim 2011), as well as some modifications of them (Li et al. 2004; Alcalá and Ciccone 2004; Ferrieri 2006; Squalli and Wilson 2011).

Although it is true that when it comes to deciding between Non-TS and TS measures the literature is somewhat mixed; in our opinion, the latter are more pertinent than the former. There still exists a heated debate and considerable disagreement, however, regarding which one of the TS-proposed measures more adequately captures trade openness. Harrison (1996) argued, for example, that the simplest openness measures are those based on the share of trade flows in GDP. Consequently, in most empirical studies, the standard summary measure of trade openness (the one we call 'nominal trade shares' (hereafter NTS)) is given by $(X+M) / G D P$ (see Yanikkaya 2003; Lee, Ricci, and Rigobon 2004; Rodrik, Subramanian, and Trebbi 2004; Kim and Lin 2009; Kim 2011; Sakyi et al. 2012; Gries and Redlin 2012).

This conventional measure, however, has come in recent years under severe criticism, not only for lack of theoretical foundation but also, most importantly, because it seems to measure country size and international integration of countries rather than their true trade openness. For this reason, several modified versions of the NTS measure have been recently employed in empirical studies to address some of its limitations. In particular, there is an ample discussion about the way exports, imports, and GDP are measured; that is, about the use of nominal trade shares or real trade shares (see Alcalá and Ciccone 2004; Rodrik, Subramanian, and Trebbi 2004; Alesina, Spolaore, and Wacziarg 2005). Additionally, there is an intense debate regarding the use of single trade share or composite trade share measures (see Squalli and Wilson 2011).

As for the nominal or real measures issue, Alcalá and Ciccone (2004) have argued that it is theoretically more appealing to use real ones. These authors define 'real international trade openness (RTS)' as nominal exports plus nominal imports relative to purchasing power parity (PPP) adjusted GDP. This is important because, in accordance with the Balassa-Samuelson hypothesis, productivity gains are greater in the tradable manufacturing sector than in the non-tradable service sector. This result would lead to an increase in the relative price of services of 
non-tradables and a decrease in the conventionally measured international trade openness. Therefore, using the NTS measure could result in an estimate of the trade openness effect on income and/or economic growth that is biased downwards. Using real openness (RTS), however, would eliminate 'distortions due to crosscountry differences in the relative price of nontradable goods' (Alcalá and Ciccone 2004, 614).

It is important to note that the argument raised by Alcalá and Ciccone (2004) has not gone down well with Rodrik, Subramanian, and Trebbi (2004). This is because using PPP-adjusted GDP as the denominator for the RTS indicator drives up measured trade openness and 'generates a positive correlation between income and openness that is entirely spurious' (Rodrik, Subramanian, and Trebbi 2004, 159). Alesina, Spolaore, and Wacziarg (2005), however, stress the simultaneous use of both NTS and RTS indicators in order to address the issues raised by Alcalá and Ciccone (2004) and to allow for comparability of the results with previous studies.

More recently, regarding the issue of single or composite measures, Squalli and Wilson (2011) have also criticised the use of the NTS indicator because it overestimates (underestimates) the openness degree of small (large) trading countries. Using Penn World Table (PWT) data for 2000, they show that some of the world's largest trading countries such as the USA, Argentina, Brazil, China, and India are relatively closed economies when the NTS indicator is applied, which makes it somewhat questionable, particularly in cross-country studies. Consequently, Squalli and Wilson (2011) propose a new indicator, the 'composite trade shares (CTS)' measure, capturing the two dimensions ('an open economy must trade heavily and must be a substantial contributor to world trade' [Squalli and Wilson 2011, 1747]) the authors believe better describe trade openness.

At this point, and in order to decide which measure is more reliable, we make use of PWT 7.0 to compute the three previously mentioned indicators of openness: NTS, RTS ${ }^{6}$ and $C T S{ }^{7}$ What we call NTS is labelled as OPENC in PWT 7.0, so this implies that we can calculate RTS as OPENC times $P$ and CTS as OPENC times $W$, where $P$ stands for the domestic price level of GDP (relative to the US price level) and $W$ represents the proportion of a country's international trade relative to the average world trade. When comparing NTS to CTS, our results are generally not different to those obtained by Squalli and Wilson (2011). For example, comparing the data for just two selected countries (China and Seychelles) over the years 2000, 2005, and $2009,{ }^{8}$ we observe from Table 1 that when the NTS measure is used, China (Seychelles) ranks 92nd (3rd), 71st (5th), and 64th (1st) among the $115 \mathrm{DCs}$ for 2000, 2005, and 2009, respectively. However, when the CTS measure is used, China (Seychelles) ranks 2nd (71st), 1st (71st), and 1st (57th). It is important to recall that the results are roughly similar when we compare the RTS and the CTS measures for these two countries.

Therefore, information reported in Table 1 is a clear sign that, as Squalli and Wilson (2011) suggested, the use of single indicators (regardless of being nominal or real) tends to overestimate the openness degree of small trading countries, and 
Table 1. Penn World Tables Version 7.0: comparing trade openness measures.

\begin{tabular}{lccrr}
\hline Country & Year & NTS & RTS & CTS \\
\hline China & 2000 & $92 \mathrm{nd}$ & 99 th & 2nd \\
& 2005 & $71 \mathrm{st}$ & 85 th & $1 \mathrm{st}$ \\
& 2009 & 64 th & $72 \mathrm{nd}$ & $1 \mathrm{st}$ \\
Seychelles & & & & \\
& 2000 & $3 \mathrm{rd}$ & 9 th & $71 \mathrm{st}$ \\
& 2005 & 5 th & 13 th & $71 \mathrm{st}$ \\
& 2009 & $1 \mathrm{st}$ & 6 th & 57 th \\
\hline
\end{tabular}

Source: Authors' elaboration using data from Penn World Tables 7.0.

underestimate that of large trading ones. For this reason, in this study, we have opted for using the CTS as our trade openness indicator.

\section{Empirical methodology}

\subsection{The empirical model}

To determine the long-run impact of trade openness on income levels, we consider as our benchmark a panel cointegrated model with the following specification:

$$
\begin{array}{r}
\ln I N C O M E_{i t}=\alpha_{i}+\beta_{i} \ln O P E N N E S S_{i t}+u_{i t}, \\
i=1,2,3 \ldots, N, \quad t=1,2,3 \ldots, T
\end{array}
$$

where $I N C O M E_{i t}$ is real per capita income of country $i$ in year $t, O P E N N E S S_{i t}$ denotes a CTS measure of trade openness, ln is the logarithm operator, $\alpha_{i}$ is the country-specific fixed effect, $\beta_{i}$ are the country parameters related to trade openness, and $u_{i t}$ is the error term. The average parameter $\beta$, namely $\beta=N^{-1} \sum_{i=1}^{N} \beta_{i}$ - which reflects the long-run relationship between trade openness and income levels, is allowed to be heterogeneous across countries (see Pesaran 2006). The short-run effects and their adjustment to the long-run are captured by the error term $u_{i t}$.

\subsection{Data and descriptive statistics}

As mentioned before, we have one full sample and three subsamples. The full sample consists of 115 countries classified by the World Bank as DCs, while the three subsamples refer, respectively, to 30 low-income countries (LICs), 45 lower-middle-income countries (LMICs), and 40 upper-middle-income countries (UMICs). ${ }^{9}$ The period of analysis goes from 1970 to 2009 . We begin the analysis in 1970 not only to maximise the number of countries we have in the sample, but also because, as Vamvakidis (2002) has exhibited, the positive link between trade openness and economic growth is rather a recent phenomenon mostly driven by 
Table 2. Descriptive statistics (1970-2009 averages).

\begin{tabular}{lccccc}
\hline Variable & $\begin{array}{c}\text { Number of } \\
\text { observations }\end{array}$ & Mean & $\begin{array}{c}\text { Standard } \\
\text { deviation }\end{array}$ & Minimum & Maximum \\
\hline $\ln I N C O M E$ & 4600 & 7.755 & 0.980 & 4.767 & 10.191 \\
$\ln C T S$ & 4600 & 6.120 & 1.942 & -2.724 & 12.426 \\
\hline
\end{tabular}

Source: Authors' elaboration using PWT 7.0.

the unprecedented expansion in world trade which began in the 1970s. Data on income levels (i.e. real GDP per capita in constant 2005 PPP dollars) and the data needed to compute CTS measures are obtained from PWT 7.0 (Heston, Summers, and Aten 2011). Table 2 displays the summary statistics for these variables.

\subsection{Estimation issues}

In order to obtain consistent and unbiased estimates of $\beta$ coefficient in equation (1), various econometric issues need to be addressed. First, the issue of crosssectional dependence that results from unobserved common factors. As noted by Driscoll and Kraay (1998), if the individual variables as well as the error term $u_{i t}$ suffer from this problem, the estimated $\beta$ and its associated standard error will be biased and inconsistent. To deal with this issue, we have run the cross-sectional dependence (CD) tests for the whole sample and the three subsamples over the period 1970-2009 and the error term $u_{i t}$, and found that the associated error terms for all indicators of trade openness are plagued by cross-sectional dependence (Table 3). ${ }^{10}$

Second, by applying panel cointegration techniques to estimate equation (1), we assume that both $\ln I N C O M E_{i t}$ and $\ln O P E N N E S S_{i t}$ are integrated of order 1 (i.e. $I(1)$ ), and the error term $u_{i t}$ is stationary (i.e. $I(0)$ ). This implies that equation (1) does not suffer the omitted variable problem (see Herzer 2010; Cavalcanti, Mohaddes, and Raissi 2011), and that satisfactory inference can be made on the long-run relationship. To ensure that these conditions are satisfied, we performed panel unit root and cointegration tests that take into consideration the problem of cross-sectional dependence. These tests (see Appendix B) clearly show that for the whole sample and the three subsamples, all variables exhibit unit root properties. As for the cointegration results (see Appendix C), it happens that although we find

Table 3. CD test statistics.

\begin{tabular}{lcccc}
\hline Variable & $115 \mathrm{DC}$ & 40 UMIC & 45 LMIC & 30 LIC \\
\hline $\ln C T S$ & $85.94^{* * *}(0.168)$ & $61.58^{* * *}(0.349)$ & $38.37^{* * *}(0.193)$ & $5.44^{* * *}(0.041)$ \\
\hline
\end{tabular}

Notes: Symbol *** denotes rejection of the null hypothesis at the $1 \%$ level. In parenthesis are the average cross-correlation coefficients. The CD test statistics are Pesaran's CD tests on the residual of traditional Mean Group (MG) estimator. 
enough evidence in support of cointegration for the 115 DCs, 40 UMICs, and 45 LMICs, we are unable to find evidence of cointegration for the panel of 30 LICs. Therefore, from now on we do not consider the LIC sample separately.

\section{Empirical analysis}

In this section, we provide estimates of the long-run cointegration relationship in equation (1) for the full and the two middle-income samples. Additionally, issues of robustness of the results as well as the estimation of short-run dynamics and adjustment to the long-run are addressed.

\subsection{Estimation of long-run relationship and robustness issues}

We stated in Section 3.3 that the error term $u_{i t}$ in equation (1) is plagued by problems of cross-sectional dependence. For this reason, we estimate the long-run relationship in equation (1) using the CCEMG estimator suggested by Pesaran (2006), which augments the ordinary least squares (OLS) regression in equation (1) with the cross-sectional averages of the dependent variable $\left(\overline{\ln I N C O M E_{t}}\right)$ and the regressor $\left(\overline{\ln O P E N N E S S_{t}}\right)$. This estimator has been shown as the way to properly eliminate both strong and weak common factors in large cross-sectionally dependent panel data models, and is consistent even when the associated errors are weakly cross-sectionally dependent (see Pesaran 2006; Holly, Pesaran, and Yamagata 2010; Pesaran and Tosetti 2011). In the application of the CCEMG estimator, Pesaran (2006) assumes that the error term $\left(u_{i t}\right)$ follows a multi-factor structure defined by $u_{i t}=\vartheta_{i}^{\prime} f_{t}+\pi_{i t}$, where $f_{t}$, which is a vector of unobserved common shocks, is allowed to be stationary or non-stationary, serially correlated and possibly correlated with $\ln O P E N N E S S_{i t}$ (see Holly, Pesaran, and Yamagata 2010; Kapetanios, Pesaran, and Yamagata 2011; Cavalcanti, Mohaddes, and Raissi 2011), while the individual-specific error term $\left(\pi_{i t}\right)$ is assumed to be distributed independently of $f_{t}$ and $\ln O P E N N E S S_{i t}$ and allowed to be weakly dependent across $i$ and serially correlated over $t$. Given this, the CCEMG estimator is based on an OLS regression of the following specification:

$$
\begin{aligned}
\ln I N C O M E_{i t}= & \alpha_{i}+\beta_{i} \ln O P E N N E S S_{i t} \\
& +b_{i 0} \overline{\ln I N C O M E_{i t}}+b_{i 1} \overline{\ln O P E N N E S S_{i t}}+\varepsilon_{i t}
\end{aligned}
$$

where the included cross-sectional averages $\left(\overline{\ln I N C O M E_{t}}\right)$ and $\left(\overline{\ln O P E N N E S S_{t}}\right)$ only serve as proxies for the common factors and may not have any interpretable meaning (see Pesaran 2006). The coefficient of interest is computed as the simple average of the $N$ countries (i.e. $\hat{\beta}=N^{-1} \sum_{i=1}^{N} \hat{\beta}_{i}$ ).

To assess the robustness of Pesaran's CCEMG results, we also estimate equation (1) by two other unbiased estimators - the group mean FMOLS and the group mean DOLS - suggested by Pedroni $(2000,2001)$, which capture the impact of 
Table 4. Long-run results for 115 developing countries.

\begin{tabular}{lc}
\hline & $\operatorname{lnCTS}$ \\
\hline Whole sample & \\
CCEMG & $0.131^{* * *}(0.015)$ \\
FMOLS & $0.167^{* * *}(0.005)$ \\
DOLS & $0.170^{* * *}(0.005)$ \\
Upper-middle-income countries & \\
CCEMG & $0.157^{* * *}(0.025)$ \\
FMOLS & $0.169^{* * *}(0.009)$ \\
DOLS & $0.180^{* * *}(0.008)$ \\
Lower-middle-income countries & \\
CCEMG & \\
FMOLS & $0.145^{* * *}(0.019)$ \\
DOLS & $0.140^{* * *}(0.008)$ \\
\hline
\end{tabular}

Notes: Dependent variable $\ln I N C O M E_{i t}$. Standard errors are reported in parenthesis. Symbol *** denotes rejection of the null hypothesis at the $1 \%$ significance level.

cross-sectional dependence through common time effects. According to Pedroni (2001), these estimators - based on the between-dimension of the panel - are promising in estimating the true mean value of $\beta$ in equation (1) in heterogeneous cointegrated panels. Moreover, a consistent and efficient estimation of cointegration vector is achieved when these estimators (i.e. FMOLS and DOLS) are used, in particular where non-stationarity, endogeneity of regressors, and serial correlation problems are suspected. Table 4 reports the estimated CCEMG, FMOLS, and DOLS results for the 115 DCs, 40 UMICs, and 45 LMICs.

Starting with the full sample, the Pesaran's CCEMG estimator clearly reveals that the trade openness' impact on income is positive (0.131) and highly significant. The results are roughly the same when we use both the Pedroni's group mean FMOLS and DOLS estimators, thereby clearly showing that there is a robust longrun relationship between trade openness and the level of income. The estimated coefficients are, however, smaller ${ }^{11}$ (and statistically superior) than those reported by other studies. (e.g. Frankel and Romer 1999; Herzer 2013). With respect to subsamples, it is worth noticing that, regardless of the estimator employed, the impact of trade on income is higher for the UMICs than for the LMICs.

The mere fact that the results for the whole sample reveal a positive and statistically significant relationship between trade openness and the level of income does not necessarily mean that each individual country benefits from trade. For this reason, we report the country-level CCEMG results in Table 5. As expected, they show considerable heterogeneity, going from -0.003 (Venezuela) to 0.777 (Maldives). It is worth emphasising that out of the 115 countries, trade openness has statistically significant positive effect on the level of income in 78 countries, no statistically significant effect in 30 countries, and statistically significant negative effect in 7 countries. 
Table 5. CCEMG country-specific results.

\begin{tabular}{|c|c|c|c|}
\hline Country & $\ln C T S$ & Country & $\ln C T S$ \\
\hline \multicolumn{4}{|c|}{40 Upper-middle-income countries } \\
\hline Albania & $0.121^{* * *}(0.039)$ & Lebanon* & $0.266^{* * *}(0.045)$ \\
\hline Algeria* & $0.025(0.025)$ & Malaysia* & $0.358^{* * *}(0.018)$ \\
\hline Antigua and Barbuda & $0.350^{* * *}(0.053)$ & Maldives & $0.777^{* * *}(0.093)$ \\
\hline Argentina & $0.059^{* * *}(0.023)$ & Mauritius* & $0.350^{* * *}(0.063)$ \\
\hline Botswana* & $0.422^{* * *}(0.093)$ & Mexico* & $0.044(0.026)$ \\
\hline Brazil $^{\star}$ & $0.092^{* * *}(0.024)$ & Namibia* & $0.138^{* * *}(0.028)$ \\
\hline Bulgaria* & $0.280^{* * *}(0.079)$ & Panama* & $0.074(0.053)$ \\
\hline Chile" & $0.218^{*}(0.131)$ & Peru* & $0.184^{* * *}(0.027)$ \\
\hline China Version $1^{*}$ & $0.208^{* * *}(0.037)$ & Romania* & $0.112^{* * *}(0.021)$ \\
\hline Colombia* & $0.129^{* * *}(0.046)$ & Seychelles & $-0.054(0.062)$ \\
\hline Costa Rica & $0.065^{* *}(0.032)$ & South Africa* & $0.153^{* * *}(0.024)$ \\
\hline $\mathrm{Cuba}^{*}$ & $0.141^{* * *}(0.019)$ & St. Kitts \& Nevis & $0.293^{* *}(0.138)$ \\
\hline Dominica* & $0.612^{* * *}(0.085)$ & St. Lucia & $0.227^{* * *}(0.067)$ \\
\hline Dominican Republic & $-0.016(0.029)$ & $\begin{array}{r}\text { St. Vincent \& } \\
\text { Grenadines }\end{array}$ & $-0.034(0.064)$ \\
\hline Ecuador* & $0.142^{* *}(0.052)$ & Suriname & $-0.073^{* *}(0.029)$ \\
\hline Gabon* & $0.257^{* * *}(0.061)$ & Thailand" & $0.407^{* * *}(0.025)$ \\
\hline Grenada & $0.237^{* *}(0.122)$ & Tunisia & $0.049(0.043)$ \\
\hline $\operatorname{Iran}^{*}$ & $0.205^{* * *}(0.028)$ & Turkey* & $0.080^{* * *}(0.020)$ \\
\hline Jamaica* & $-0.100(0.077)$ & Uruguay & $-0.193^{* *}(0.068)$ \\
\hline Jordan* & $0.186^{* * *}(0.037)$ & Venezuela & $-0.003(0.049)$ \\
\hline \multicolumn{4}{|c|}{45 Lower-middle-income countries } \\
\hline Angola* & $0.017(0.055)$ & Mauritania & $0.067^{* * *}(0.017)$ \\
\hline Belize & $0.072(0.063)$ & $\begin{array}{r}\text { Micronesia, Fed. } \\
\text { Sts }\end{array}$ & $0.245^{* *}(0.111)$ \\
\hline Bhutan & $0.289^{* * *}(0.091)$ & Mongolia & $-0.080(0.078)$ \\
\hline Bolivia* & $0.067^{* *}(0.029)$ & Morocco & $0.040(0.059)$ \\
\hline Cameroon* & $0.245^{* *}(0.093)$ & Nicaragua & $0.084(0.050)$ \\
\hline Cape Verde & $0.210^{* *}(0.087)$ & Nigeria* & $0.070(0.054)$ \\
\hline Republic of Congo & $0.084(0.063)$ & Pakistan* & $0.228^{* * *}(0.036)$ \\
\hline Cote d'Ivoire* & $-0.005(0.040)$ & $\begin{array}{r}\text { Papau New } \\
\text { Guinea }\end{array}$ & $0.286^{* *}(0.140)$ \\
\hline Djibouti & $0.125^{* *}(0.061)$ & Paraguay* & $0.100^{* * *}(0.032)$ \\
\hline Egypt ${ }^{*}$ & $0.130 * *(0.060)$ & Philippines & $-0.011(0.021)$ \\
\hline El Salvador* & $0.189^{* * *}(0.022)$ & Samoa & $0.014(0.059)$ \\
\hline Fiji & $0.201^{* * *}(0.061)$ & $\begin{array}{l}\text { Sao Tome and } \\
\text { Principe }\end{array}$ & $-0.048(0.049)$ \\
\hline Ghana & $0.052^{* * *}(0.014)$ & Senegal & $0.147^{* * *}(0.042)$ \\
\hline Guatemala* & $0.022(0.034)$ & Solomon Islands & $0.137^{* * *}(0.035)$ \\
\hline Guyana & $0.191^{* *}(0.097)$ & Sri Lanka & $0.187^{* * *}(0.045)$ \\
\hline Honduras* & $-0.155^{* * *}(0.027)$ & Sudan & $0.118^{* * *}(0.020)$ \\
\hline India* & $0.189^{* * *}(0.030)$ & Swaziland* & $0.379^{* * *}(0.040)$ \\
\hline Indonesia* & $0.280^{* * *}(0.044)$ & Syria* & $0.080(0.058)$ \\
\hline $\operatorname{Iraq}^{*}$ & $0.188^{* * *}(0.026)$ & Tonga & $0.055(0.081)$ \\
\hline
\end{tabular}


Table 5. (Continued).

\begin{tabular}{lrrr}
\hline Country & \multicolumn{1}{c}{$\ln C T S$} & Country & \multicolumn{1}{c}{$\ln C T S$} \\
\hline Kiribati & $0.012(0.126)$ & Vanuatu & $0.324^{* * *}(0.081)$ \\
Laos & $0.046^{* * *}(0.009)$ & Vietnam* & $0.301^{* * *}(0.039)$ \\
Lesotho & $0.072(0.045)$ & Zambia* & $0.425^{* * *}(0.037)$ \\
Marshall Islands & $0.263^{* * *}(0.034)$ & & \\
& & & \\
30 Low-income countries & & & \\
Afghanistan & $-0.262^{* * *}(0.081)$ & Kenya* & $-0.011(0.022)$ \\
Bangladesh & $0.120^{* * *}(0.029)$ & Liberia & $0.403^{* * *}(0.036)$ \\
Benin & $-0.048(0.042)$ & Madagascar & $0.038(0.029)$ \\
Burkina Faso & $-0.021(0.033)$ & Malawi & $0.128^{* *}(0.065)$ \\
Burundi & $0.093^{* * *}(0.025)$ & Mali & $-0.117^{* *}(0.047)$ \\
Cambodia & $0.132^{* * *}(0.022)$ & Mozambique & $0.010(0.027)$ \\
Central African Republic & $0.198^{* * *}(0.037)$ & Nepal & $0.080^{* * *}(0.015)$ \\
Chad & $0.303^{* * *}(0.049)$ & Niger & $0.245^{* * *}(0.058)$ \\
Comoros & $0.245^{* * *}(0.039)$ & Rwanda & $-0.024(0.071)$ \\
Dem. Rep. Congo & $0.330^{* * *}(0.059)$ & Sierra Leone & $0.018^{* * *}(0.059)$ \\
Ethiopia & $0.143^{* * *}(0.035)$ & Somalia & $0.064^{* * *}(0.008)$ \\
The Gambia & $-0.188^{* * *}(0.028)$ & Tanzania & $0.052^{* * *}(0.018)$ \\
Guinea & $0.052^{* * *}(0.015)$ & Togo & $0.110^{* * *}(0.030)$ \\
Guinea-Bissau & $-0.193^{* * *}(0.066)$ & Uganda & $0.173^{* * *}(0.038)$ \\
Haiti & $0.171^{* * *}(0.019)$ & Zimbabwe & $0.032(0.018)$ \\
\hline
\end{tabular}

Notes: Dependent variable $\ln I N C O M E_{i t}$. Standard errors are reported in parenthesis. Symbols $* * *{ }^{* * *}$, $\left.{ }^{*}\right]$ denote rejection of the null hypothesis at the $1 \%[5 \%, 10 \%]$ significance levels. Symbol * denotes countries with an average openness degree above the sample average.

As an additional point, we have attempted to assess whether the results across countries differ not only according to their income level but also to their degree of openness. As it is evident from Table 5, out of the $53^{12}$ countries with an average openness degree above the sample average, 38 have positive and statistically significant trade - income effect, 14 has no effect with only Honduras having a negative and statistically significant effect. This implies that countries more integrated into the world economy in terms of trade generally tend to benefit more from it.

\subsection{Causality, short-run dynamics, and adjustment to the long run}

We have just shown that a positive long-run relationship exists between trade openness and income levels. Another important issue is to determine the shortand long-run causal relationship between the two variables and, in particular, whether trade openness also affects the rate of income growth. Moreover, we are also interested in detecting the long-run Granger causality, given that our long-run cointegration results between trade openness and income only imply causality in one direction (see Herzer 2013). This is crucial because, as the long-run results have revealed, trade benefits tend to increase with the level of income. To deal with 
this issue, we estimate a panel vector error correction model using the following equations:

$$
\begin{aligned}
& \Delta \ln I N C O M E_{i t}=c_{1 i}+\sum_{j=1}^{p} \phi_{11 j} \Delta \ln I N C O M E_{i, t-j} \\
& +\sum_{j=1}^{p} \phi_{12 j} \Delta \ln \text { PPENNESS }_{i, t-j}+\gamma_{1} e c t_{i, t-1}+v_{i t} \\
& \Delta \ln O P E N N E S S_{i t}=c_{2 i}+\sum_{j=1}^{p} \phi_{21 j} \Delta \ln I N C O M E_{i, t-j} \\
& +\sum_{j=1}^{p} \phi_{22 j} \Delta \ln \text { PPENNESS }_{i, t-j}+\gamma_{2} e \operatorname{et}_{i, t-1}+v_{i t}
\end{aligned}
$$

where the symbol $\Delta$ is the first difference operator, $\Delta \ln I N C O M E_{i t}$ represents the rate of income growth, and $e c t_{i, t-1}$ is the lagged error correction term computed from the long-run cointegration relationship of equation (1) with the formula $e c t_{i t}=\ln I N C O M E_{i t}-\hat{\alpha}-\hat{\beta}_{i} \ln O P E N N E S S_{i t}$. Here we investigate two important issues. First, given that a significant coefficient on the lagged error correction terms provides evidence in support of the existence of a long-run relationship, we need to determine whether this is the case. We do this by assessing whether the coefficients on the lagged error correction terms are statistically different from zero (i.e. $\gamma_{1} \neq 0$ and $\gamma_{2} \neq 0$ ). If this were not the case for at least one of them, we would not be able to rely on the panel cointegration results, which establish a long-run cointegration relationship in equation (1), and hence there would not be any evidence for long-run Granger causality. Second, we determine whether there is any evidence of a short-run Granger causality by implementing a $\chi^{2}$-test for the null hypothesis of short-run Granger non-causality on the lags of the short-run coefficients. If the null hypothesis were to be rejected, there would exist evidence in favour of a short-run Granger causality. To implement the short- and long-run Granger causality tests, we estimate equations (3) and (4) by CCEMG. The results, reported in Table 6, show that the adjustment coefficient is negative in all cases and highly significant (at the $1 \%$ level), indicating that the long-run cointegrating relationship for equation (1) truly holds.

The rejection of the $\chi^{2}$-test for the null hypothesis of long-run Granger noncausality on the coefficients of $e c t_{i, t-1}$ indicates a long-run bi-directional Granger causality between openness and the level of income, suggesting that increased openness is both a cause and a consequence of increased levels of income. This result is consistent for the whole sample and the two middle-income group samples. The evidence in favour of a short-run Granger causality is, once again, quite conclusive not only for the whole sample but also for the two middle-income groups in both directions. 
Table 6. Causality results for 115 developing countries - CCEMG.

\begin{tabular}{|c|c|c|}
\hline & $\ln Y_{i t}$ & $\ln C T S_{i t}$ \\
\hline \multicolumn{3}{|l|}{ Whole sample } \\
\hline$e c t_{i, t-1}$ & $-0.183^{* * *}$ & $-0.315^{* * *}$ \\
\hline$e c t_{i, t-1}\left[\chi^{2}(1)\right]$ & $161.11^{* * *}$ & $204.65^{* * *}$ \\
\hline$\Delta \ln Y_{i, t-1}$ & & $0.793^{* * *}$ \\
\hline$\Delta \ln Y_{i, t-1}\left[\chi^{2}(1)\right]$ & & $42.36^{* * *}$ \\
\hline$\Delta \ln O_{i, t-1}$ & $0.054^{* * *}$ & \\
\hline$\Delta \ln O_{i, t-1}\left[\chi^{2}(1)\right]$ & $36.43^{* * *}$ & \\
\hline \multicolumn{3}{|c|}{ Upper-middle-income countries } \\
\hline$e c t_{i, t-1}$ & $-0.147^{* * *}$ & $-0.306^{* * *}$ \\
\hline$e c t_{i, t-1}\left[\chi^{2}(1)\right]$ & $62.32 * * *$ & $113.35^{* * *}$ \\
\hline$\Delta \ln Y_{i, t-1}$ & & $0.691^{* * *}$ \\
\hline$\Delta \ln Y_{i, t-1}\left[\chi^{2}(1)\right]$ & & $12.04^{* * *}$ \\
\hline$\Delta \ln O_{i, t-1}$ & $0.062^{* * *}$ & \\
\hline$\Delta \ln O_{i, t-1}\left[\chi^{2}(1)\right]$ & $20.23^{* * *}$ & \\
\hline \multicolumn{3}{|c|}{ Lower-middle-income countries } \\
\hline$e c t_{i, t-1}$ & $-0.151^{* * *}$ & $-0.375^{* * *}$ \\
\hline$e c t_{i, t-1}\left[\chi^{2}(1)\right]$ & $64.48^{* * *}$ & $111.36^{* * *}$ \\
\hline$\Delta \ln Y_{i, t-1}$ & & $0.685^{* * *}$ \\
\hline$\Delta \ln Y_{i, t-1}\left[\chi^{2}(1)\right]$ & & $16.79^{* * *}$ \\
\hline$\Delta \ln O_{i, t-1}$ & $0.067^{* * *}$ & \\
\hline$\Delta \ln O_{i, t-1}\left[\chi^{2}(1)\right]$ & $19.47^{* * *}$ & \\
\hline
\end{tabular}

Notes: Symbol ${ }^{* * *}$ indicates rejection of the null hypothesis at the $1 \%$ significance level. $Y=I N C O M E$, $O=O P E N N E S S$.

Summing up, the main conclusion is that both the long- and short-run Granger causality are bi-directional for the whole sample and the two subgroups, suggesting that trade openness is both a cause and a consequence of the level of income of countries.

\section{Concluding remarks}

This paper has investigated the extent to which trade openness has had an impact on the levels of income and rates of growth in a sample of $115 \mathrm{DCs}$ for the period 1970-2009. In order to address this issue, it has made use of a CTS measure of trade openness as this has proved to be the most reliable. In addition, the paper has employed non-stationary heterogeneous panel cointegration techniques to cope with the drawbacks of cross-sectional and homogeneous panel data techniques, and also to deal with the potential endogeneity of trade openness. In particular, and for the sake of robustness, three alternative estimators have been computed. Additionally, to assess whether the level of income is crucial for a country to benefit from international trade, the analysis has been developed not only for the full sample but also for three exhaustive and mutually exclusive groups of countries: low-income, lower-middle income and upper-middle-income countries. 
The results suggest the existence of a long-run cointegration relationship between trade openness and the levels of income for the whole sample and two subsamples (those including the middle-income countries). The long-run coefficients generally indicate a positive and significant effect of trade openness on the income level, thereby implying that the former promotes the latter. The longrun Granger non-causality test further reveals that this effect is bi-directional, suggesting that trade is both a cause and a consequence of the level of income. It is also convenient to note that the link between openness and income is higher for the UMICs than for the LMICs. Summing up, the results provide support for a positive long-run heterogeneous openness-income relationship, in which the level of income that a country has initially reached seems to be quite relevant. $^{13}$

On the contrary, the results for the sample of LICs are not encouraging as they show not enough evidence to support a long-run cointegration relationship between trade openness and the level of income. In any case, the results obtained do not imply that, generally speaking, trade openness negatively affects the levels of income and economic growth in this type of countries, but they rather call for policy interventions that could help deepen their trade integration across the globe and change their structure of trade. Should these policies be implemented, these countries would most likely benefit from additional increases in their openness degrees.

As for the short-run Granger non-causality results, the paper has found quite robust results. Specifically, it has shown that there exists a short-run relationship between trade openness and economic growth that, once again, is bi-directional.

\section{Acknowledgements}

Earlier version of the paper was presented at the 2013 Conference on Development Economics and Policy, June 21-22, 2013, Munich, Germany, hosted by the Ifo Institute and the University of Munich. We are grateful to Dierk Herzer and three anonymous referees of this journal for their insightful comments and suggestions. All remaining errors are those of the authors.

\section{Supplemental data}

Supplemental data for this article can be accessed here.

\section{Notes}

1. This being the case, it should be mentioned that the import substitution industrialisation strategies formulated by Prebisch (1950) and Singer (1950) have the opposite view.

2. See cross-sectional studies by Frankel and Romer (1999) and Rodríguez and Rodrik (2001) and Panel GMM studies by Dollar and Kraay (2003) and Felbermayr (2005). As Herzer (2013) notes most of these cross-sectional and panel studies report either insignificant effect of trade on income/growth or very high significant effect.

3. The complete list of countries is presented in Appendix A. 
4. As stated by Gersbach, Schneider, Schneller $(2013,33)$, this may be so because "higher openness tends to encourage more investment in basic research which, in turn, yields a larger share of leading sectors".

5. For an exhaustive review, readers are referred to Singh (2010).

6. $R T S=\frac{(X+M) / E R S U S}{G D P / P P P S U S}=\frac{((X+M) / E R S U S)}{(G D P)(E R S U S / P)}=O P E N C \times P$ where $E R \$ U S$ refers to Exchange Rate Dollar and PPP $\$ U S$ refers to PPP Dollar.

7. $C T S=C T S_{i}=\frac{(X+M)_{i}}{(1 / N) \sum_{j=1}^{N}(X+M)_{j}} \frac{(X+M)_{i}}{G D P_{i}}=\frac{(X+M)_{i}}{(1 / N) \sum_{j=1}^{N}(X+M)_{j}} \times O P E N C_{i}=$ $W \times O P E N C$. This indicator has been computed for the full sample of 157 developing and developed countries (see Appendix A), although the information later used refers to the 115 developing countries we are interested in.

8. To save space, however, the results for all the 115 developing countries considered are not reported; they are available from the authors upon request.

9. Readers are referred to World Bank Classification of economies, July 2011, http://data.worldbank.org/about/country-classifications/country-and-lending-groups for further details.

10. For brevity, we report only the CD test statistics associated with the error term, $u_{i t}$. For the individual variables (i.e. the OLS residuals from $A D F(p)$ regressions of $I N C O M E_{i t}$ and the OPENNESS it indicator), which also show evidence of crosssectional dependence, $\mathrm{CD}$ test statistics are available from the authors upon request.

11. According to Squalli and Wilson (2011), the small but statistically significant coefficient of trade openness on the level of income results from different combinations of changes of $W$ and/or NTS that combine to increase CTS.

12. Out of these 53 countries (identified in Table 5 with the symbol *), 29 are uppermiddle-income countries, 22 are lower-middle-income countries with only 2 being low-income countries.

13. An interesting issue for further research is the use of panel smooth transition regression techniques in order to determine, without previous splitting of the countries in the sample, the threshold over which openness has a positive impact on income.

\section{References}

Alcalá, F., and A. Ciccone. 2004. "Trade and Productivity." Quarterly Journal of Economics 119: 613-646.

Alesina, A., E. Spolaore, and R. Wacziarg. 2005. "Trade, Growth and the Size of Countries." In Handbook of Economic Growth, edited by P. Aghion and S.N. Durlauf, Vol. 1B, 1499-1542. Philadelphia, PA: Elsevier.

Almeida, R., and A.M. Fernandes. 2008. "Openness and Technological Innovations in Developing Countries: Evidence from Firm-Level Surveys." Journal of Development Studies 44: 701-727.

Ben-David, D., and M. Loewy. 1998. "Free Trade, Growth, and Convergence.” Journal of Economic Growth 3: 143-170.

Ben-David, D., and M. Loewy. 2000. "Knowledge Dissemination, Capital Accumulation, Trade, and Endogenous Growth." Oxford Economic Papers 52: 637-650.

Ben-David, D., and M. Loewy. 2003. "Trade and the Neoclassical Growth Model.” Journal of Economic Integration 18: 1-16.

Brunner, A.D. 2003. "The Long-Run Effects of Trade on Income and Income Growth." $I M F$ Working Paper WP/03/37. Washington, DC: IMF Institute.

Cavalcanti, T.V.de.V., K. Mohaddes, and M. Raissi. 2011. "Growth, Development and Natural Resources: New Evidence Using a Heterogeneous Panel Analysis." The Quarterly Review of Economics and Finance 51: 305-318.

Chang, R., L. Kaltani, and N.V. Loayza. 2009. "Openness can be Good for Growth: The role of Policy Complementarities." Journal of Development Economics 90: 3349. 
Coe, D.T., E. Helpman, and A.W. Hoffmaister. 2009. "International R\&D Spillovers and Institutions." European Economic Review 53: 723-741.

De Lombaerde, P. 2009. “On the Dynamic Measurement of Economic Openness.” Journal of Policy Modeling 31: 731-736.

Dollar, D., and A. Kraay. 2003. "Institutions, Trade, and Growth." Journal of Monetary Economics 50: 133-162.

Dowrick, S., and J. Golley. 2004. "Trade Openness and Growth: Who Benefits?" Oxford Review of Economic Policy 20: 38-56.

Driscoll, J.C., and A.C. Kraay. 1998. "Consistent Covariance Matrix Estimation with Spatially Dependent Panel Data." Review of Economics and Statistics 80: 549-560.

Dufrénot, G., V. Mignon, and C. Tsangarides. 2010. "The Trade-Growth Nexus in the Developing Countries: A Quantile Regression Approach.” Review of World Economics 146: 731-761.

Estrada, M.A.R., and S.F. Yap. 2006. "The Openness Growth Monitoring Model (OGMModel)." Journal of Policy Modeling 28: 235-246.

Felbermayr, G.J. 2005. "Dynamic Panel Data Evidence on the Trade-Income Relation." Review of World Economics 14 (4): 583-611.

Ferrieri, G. 2006. "A Method for Measuring International Openness." Social Indicators Research 77: 245-255.

Frankel, J.A., and D. Romer. 1999. "Does Trade Cause Growth?" American Economic Review 89 (2): 379-399.

Freund, C., and B. Bolaky. 2008. “Trade, Regulations, and Income.” Journal of Development Economics 87: 309-321.

Gersbach, H., M.T. Schneider, and O. Schneller. 2013. "Basic Research, Openness, and Convergence." Journal of Economic Growth 18: 33-68.

Greenaway, D., W. Morgan, and P. Wright. 1998. "Trade Reform, Adjustment and Growth: What Does the Evidence Tell Us?" The Economic Journal 108: 1547-1561.

Gries, T., and M. Redlin. 2012. "Trade Openness and Economic Growth: A Panel Causality Analysis.” Working Paper No. 2011-06. Center for International Economics. Germany: University of Paderborn.

Grossman, G.M., and E. Helpman. 1990. "Comparative Advantage and Long-Run Growth.” American Economic Review 80: 796-815.

Grossman, G.M., and E. Helpman. 1991. Innovations and Growth in the Global Economy. Cambridge: MIT Press.

Harrison, A. 1996. "Openness and Growth: A Time-Series, Cross-country Analysis for Developing Countries." Journal of Development Economics 48: 419-447.

Herzer, D. 2010. "The Long-Run Relationship Between Outward FDI and Total Factor Productivity: Evidence for Developing Countries.” Discussion Paper No. 199. Germany: Ibero-America Institute for Economic Research, Georg-August University of Gottingen.

Herzer, D. 2013. "Cross-country Heterogeneity and the Trade-Income Relationship." World Development 44: 194-211.

Heston, A., R. Summers, and B. Aten. 2011. Penn World Table Version 7.0. Philadelphia, PA: Center for International Comparisons of Production, Income and Prices at the University of Pennsylvania.

Holly, S., M.H. Pesaran, and T. Yamagata. 2010. "A Spatio-temporal Model of House Prices in the USA." Journal of Econometrics 158: 160-173.

Irwin, D.A., and M. Tervio. 2002. "Does Trade Raise Income?: Evidence from the Twentieth Century." Journal of International Economics 58: 1-18.

Kapetanios, G., M.H. Pesaran, and T. Yamagata. 2011. "Panels with Nonstationary Multifactor Error Structures." Journal of Econometrics 160: 326-348.

Kali, R., F. Méndez, and J. Reyes. 2007. "Trade Structure and Economic Growth.” The Journal of International Trade \& Economic Development 16: 245-269. 
Kim, D. 2011. “Trade, Growth and Income.” The Journal of International Trade \& Economic Development 20: 677-709.

Kim, D., and S. Lin. 2009. "Trade and Growth at Different Stages of Economic Growth." Journal of Development Studies 45: 1211-1224.

Kim, D.-H., S.-C. Lin, and Y.-B. Suen. 2011. "Nonlinearity Between Trade Openness and Economic Development.” Review of Development Economics 15: 279-292.

Lee, H.Y., L.A. Ricci, and R. Rigobon. 2004. “Once Again, Is Openness Good for Growth?” Journal of Development Economics 75: 451-472.

Li, K., R. Morck, F. Yang, and B. Yeung. 2004. "Firm-Specific Variation and Openness in Emerging Markets." The Review of Economics and Statistics 86: 658-669.

López, R.A. 2005. "Trade and Growth: Reconciling the Macroeconomic and Microeconomic Evidence." Journal of Economic Surveys 19: 623-648.

Noguer, M., and M. Siscart. 2005. "Trade Raises Income: A Precise and Robust Result." Journal of International Economics 65: 447-460.

Pedroni, P. 2000. "Fully Modified OLS for Heterogeneous Cointegrated Panels." Advances in Econometrics 15: 93-130.

Pedroni, P. 2001. "Purchasing Power Parity Tests in Cointegrated Panels." The Review of Economics and Statistics 83: 727-731.

Pedroni, P. 2007. "Social Capital, Barriers to Production and Capital Shares: Implications for the Importance of Parameter Heterogeneity from a Non-stationary Panel Approach." Journal of Applied Econometrics 22: 429-451.

Perera-Tallo, F. 2003. "Growth due to Globalisation." International Economic Review 44: 651-676.

Pesaran, M.H. 2006. "Estimation and Inference in Large Heterogeneous Panels with a Multifactor Error Structure." Econometrica 74: 967-1012.

Pesaran, M.H. 2007. "A Simple Panel Unit Root Test in the Presence of Cross Section Dependence.” Journal of Applied Econometrics 22: 265-312.

Pesaran, M.H., and E. Tosetti. 2011. "Large Panels with Common Factors and Spatial Correlations." Journal of Econometrics 161: 182-202.

Prebisch, R. 1950. "The Economic Development of Latin America and Its Principal Problems." Economic Bulletin for Latin America 7: 1-22.

Rassekh, F. 2007. "Is International Trade More Beneficial to Lower Income Economies? An Empirical Inquiry." Review of Development Economics 11: 159-169.

Rivera-Batiz, L.A., and P.M. Romer. 1991. "International Trade with Endogenous Technological Change.” European Economic Review 35: 971-1001.

Rodríguez, F., and D. Rodrik. 2001. "Trade Policy and Economic Growth: A Skeptic's Guide to the Cross-national Evidence." In NBER Macroeconomics Annual 2000, edited by B.S. Bernanke and K. Rogoff, Vol. 15, 261-338. Cambridge, MA: MIT Press.

Rodrik, D. 1999. "The New Global Economy and Developing Countries: Making Openness Work." Policy Essay No. 24. Washington, DC: Overseas Development Council.

Rodrik, D., A. Subramanian, and F. Trebbi. 2004. "Institutions Rule: The Primacy of Institutions over Geography and Integration in Economic Development.” Journal of Economic Growth 9: 131-165.

Romer, P.M. 1990. "Endogeneous Technical Change." Journal of Political Economy 98 : S71-S102.

Sachs, J.D., and A. Warner. 1995. "Economic Reform and the Process of Global Integration." Brookings Papers on Economic Activity 1 (1): 1-118.

Sakyi, D., J. Villaverde, A. Maza, and K.R. Chittedi. 2012. "Trade Openness, Growth and Development: Evidence from Heterogeneous Panel Cointegration Analysis for Middle-Income Countries." Cuadernos de Economía Special Issue, 31 (57): 21-40.

Salinas, G., and A. Aksoy. 2006. "Growth Before and After Trade Liberalisation." World Bank Policy Research Paper No. 4062. Washington, DC: World Bank.

Singer, H. 1950. "The Distribution of Gains Between Investing and Borrowing Countries." American Economic Review, Papers and Proceedings 40: 473-485. 
Singh, T. 2010. "Does International Trade Cause Economic Growth? A Survey." World Economy 33 (11): 1517-1564.

Spilimbergo, A. 2000. "Growth and Trade: The North Can Lose." Journal of Economic Growth 5 (2): 131-146.

Squalli, J., and K. Wilson. 2011. "A New Measure of Trade Openness.” World Economy 34 (10): $1745-1770$.

Vamvakidis, A. 2002. "How Robust Is the Growth-Openness Connection? Historical Evidence." Journal of Economic Growth 7 (1): 57-80.

Wacziarg, R., and K.H. Welch. 2008. "Trade Liberalisation and Growth: New Evidence." The World Bank Economic Review 22 (2): 187-231.

Yanikkaya, H. 2003. "Trade Openness and Economic Growth: A Cross-country Empirical Investigation." Journal of Development Economics 72 (1): 57-89.

Young, A. 1991. "Learning by Doing and the Dynamic Effects of International Trade." The Quarterly Journal of Economics 106 (2): 369-405.

\section{Appendix A. List of countries included in the analysis}

30 low-income countries

Afghanistan, Bangladesh, Benin, Burkina Faso, Burundi, Cambodia, Central African Republic, Chad, Comoros, Democratic Republic of the Congo, Ethiopia, The Gambia, Guinea, Guinea-Bissau, Haiti, Kenya, Liberia, Madagascar, Mali, Malawi, Mozambique, Nepal, Niger, Rwanda, Sierra Leone, Somalia, Tanzania, Togo, Uganda, and Zimbabwe.

\section{5 lower-middle-income countries}

Angola, Belize, Bhutan, Bolivia, Cameroon, Cape Verde, Republic of Congo, Cote d'Ivoire, Djibouti, Egypt, El Salvador, Fiji, Ghana, Guatemala, Guyana, Honduras, India, Indonesia, Iraq, Kiribati, Laos, Lesotho, Marshall Islands, Mauritania, Federated States of Micronesia, Mongolia, Morocco, Nicaragua, Nigeria, Pakistan, Papua New Guinea, Paraguay, Philippines, Samoa, Sao Tome and Principe, Senegal, Solomon Islands, Sri Lanka, Sudan, Swaziland, Syria, Tonga, Vanuatu, Vietnam, and Zambia.

\section{0 upper-middle-income countries}

Albania, Algeria, Antigua and Barbuda, Argentina, Botswana, Brazil, Bulgaria, Chile, China Version 1, Colombia, Costa Rica, Cuba, Dominica, Dominican Republic, Ecuador, Gabon, Grenada, Iran, Jamaica, Jordan, Lebanon, Malaysia, Maldives, Mauritius, Mexico, Namibia, Panama, Peru, Romania, Seychelles, South Africa, St. Kitts \& Nevis, St. Lucia, St. Vincent \& Grenadines, Suriname, Thailand, Tunisia, Turkey, Uruguay, and Venezuela.

\section{High-income countries}

Australia, Austria, Bahamas, Bahrain, Barbados, Belgium, Bermuda, Brunei, Canada, Cyprus, Denmark, Equatorial Guinea, Finland, France, Germany, Greece, Hong Kong, Hungary, Iceland, Ireland, Israel, Italy, Japan, Republic of Korea, 
Luxembourg, The Netherlands, New Zealand, Norway, Macao, Malta, Oman, Poland, Portugal, Puerto Rico, Singapore, Spain, Sweden, Switzerland, Taiwan, Trinidad \& Tobago, United Kingdom, and United States.

\section{Appendix B. Panel unit roots test results}

We have made use of panel unit root tests that allow us to treat the effect of crosssectional dependence. Specifically, the cross-sectionally augmented IPS (CIPS) test (Pesaran 2007) which incorporates cross-sectional heterogeneity is used. The panel unit root test statistics, reported in Tables B1 to B4, allow us to treat both income and all international trade openness indicators as $I(1)$ variables.

Table B1. CIPS panel unit roots test for 115 developing countries.

\begin{tabular}{lrrrr}
\hline Variables & CADF(1) & CADF $(2)$ & $C A D F(3)$ & CADF(4) \\
\hline No trend & & & & \\
$\ln I N C O M E$ & -1.867 & -1.715 & -1.769 & -1.582 \\
$\ln C T S$ & -1.760 & -1.500 & -1.462 & -1.399 \\
$\Delta \ln I N C O M E$ & $-4.175^{* * *}$ & $-3.292^{* * *}$ & $-2.969^{* * *}$ & $-2.510^{* * *}$ \\
$\Delta \ln C T S$ & $-4.474^{* * *}$ & $-3.348^{* * *}$ & $-2.873^{* * *}$ & $-2.469^{* * *}$ \\
With trend & & & & \\
$\ln I N C O M E$ & $-2.563^{* *}$ & -2.441 & -2.423 & -2.219 \\
$\ln C T S$ & -2.365 & -2.038 & -2.060 & -1.914 \\
\hline
\end{tabular}

Notes: The critical values at the $1 \%(5 \%)[10 \%]$ level for Pesaran's CIPS test statistics are $-2.140(-2.060)[-2.010]$ with no trend case, and $-2.620(-2.540)[-2.500]$ with a trend case. Symbols $* * *(* *)$ indicate rejection of the null hypothesis of non-stationary variable at the $1 \%(5 \%)$ significance levels.

Table B2. CIPS panel unit root test for 40 upper-middle-income countries.

\begin{tabular}{lllll}
\hline Variables & CADF(1) & CADF(2) & CADF $(3)$ & $C A D F(4)$ \\
\hline No trend & & & & \\
$\ln I N C O M E$ & -2.022 & -1.935 & -2.007 & -1.797 \\
$\ln C T S$ & -1.801 & -1.641 & -1.570 & -1.414 \\
$\Delta \ln I N C O M E$ & $-3.972^{* * *}$ & $-3.177^{* * *}$ & $-2.807^{* * *}$ & $-2.301^{* * *}$ \\
$\Delta \ln C T S$ & $-4.483^{* * *}$ & $-3.573^{* * *}$ & $-3.142^{* * *}$ & $-2.492^{* * *}$ \\
With trend & & & & \\
$\ln I N C O M E$ & -2.283 & -2.174 & -2.169 & -2.039 \\
$\ln C T S$ & -2.294 & -2.173 & -2.066 & -1.906 \\
\hline
\end{tabular}

Notes: The critical values at the $1 \%(5 \%)[10 \%]$ level for Pesaran's CIPS test statistics are $-2.230(-2.110)[-2.500]$ with no trend case, and $-2.720(-2.600)[-2.550]$ with a trend case. Symbol *** indicates rejection of the null hypothesis of non-stationary variable at the $1 \%$ significance level. 
Table B3. CIPS panel unit root test for 45 lower-middle-income countries.

\begin{tabular}{lllll}
\hline Variables & CADF(1) & $C A D F(2)$ & $C A D F(3)$ & $C A D F(4)$ \\
\hline No trend & & & & \\
$\ln I N C O M E$ & -1.945 & -1.769 & -1.822 & -1.630 \\
$\ln C T S$ & -1.992 & -1.716 & -1.718 & -1.514 \\
$\Delta \ln I N C O M E$ & $-4.217^{* * *}$ & $-3.453^{* * *}$ & $-2.951^{* * *}$ & $-2.417^{* * *}$ \\
$\Delta \ln C T S$ & $-4.463^{* * *}$ & $-3.315^{* * *}$ & $-2.895^{* * *}$ & $-2.460^{* * *}$ \\
With trend & & & & \\
$\ln I N C O M E$ & -2.511 & -2.379 & -2.312 & -2.073 \\
$\ln C T S$ & -2.296 & -1.946 & -1.978 & -1.765 \\
\hline
\end{tabular}

Notes: The critical values at the $1 \%(5 \%)[10 \%]$ level for Pesaran's CIPS test statistics are $-2.230(-2.110)[-2.050]$ with no trend case, and $-2.720(-2.600)[-2.550]$ with a trend case. Symbol ${ }^{* * *}$ indicates rejection of the null hypothesis of non-stationary variable at the $1 \%$ significance level.

Table B4. CIPS panel unit root test for 30 low-income countries.

\begin{tabular}{lllll}
\hline Variables & CADF(1) & CADF $(2)$ & $C A D F(3)$ & $C A D F(4)$ \\
\hline No trend & & & & \\
InINCOME & -1.451 & -1.389 & -1.533 & -1.352 \\
$\ln C T S$ & $-2.129^{*}$ & -1.954 & -1.867 & -1.815 \\
$\Delta \ln I N C O M E$ & $-4.355^{* * *}$ & $-3.312^{* * *}$ & $-3.210^{* * *}$ & $-2.640^{* * *}$ \\
$\Delta \ln C T S$ & $-4.760^{* * *}$ & $-3.360^{* * *}$ & $-2.898^{* * *}$ & $-2.340^{* * *}$ \\
With trend & & & & \\
$\ln I N C O M E$ & $-2.721^{* *}$ & -2.563 & $-2.736^{* *}$ & -2.294 \\
$\ln C T S$ & -2.501 & -2.121 & -2.230 & -2.178 \\
\hline
\end{tabular}

Notes: The critical values at the $1 \%(5 \%)[10 \%]$ level for Pesaran's CIPS test statistics are $-2.300(-2.160)[-2.080]$ with no trend case, and $-2.780(-2.650)[-2.580]$ with a trend case. Symbols ${ }^{* * *}(* *)\left[{ }^{*}\right]$ indicate rejection of the null hypothesis of non-stationary variable at the $1 \%(5 \%)[10 \%]$ significance levels. 


\section{Appendix C. Panel cointegration test results}

We have established that all the variables that enter equation (1) exhibit unit root properties. For this reason, we are able to determine whether the series are cointegrated. This would allow us to avoid any spurious regressions problems. Both the CIPS (based on residuals of MG regressions) and Pedroni's tests statistics suggest that the series are cointegrated (Tables $\mathrm{C} 1$ to $\mathrm{C} 4$ ).

Table C1. CIPS and Pedroni test statistics for 115 developing countries.

(a) CIPS test statistics (based on residuals of MG regression) ${ }^{\mathrm{a}}$

\begin{tabular}{lllll}
\hline & $\mathrm{CADF}(1)$ & $\mathrm{CADF}(2)$ & $\mathrm{CADF}(3)$ & $\mathrm{CADF}(4)$ \\
\hline $\operatorname{lnCTS}$ & $-2.432^{* * *}$ & $-2.195^{* * *}$ & $-2.154^{* * *}$ & $-2.039^{*}$ \\
\hline
\end{tabular}

(b) Pedroni's test statistics ${ }^{\text {b }}$

\begin{tabular}{|c|c|c|c|c|c|c|}
\hline \multirow[b]{3}{*}{$\ln C T S$} & \multicolumn{3}{|c|}{ No trend } & \multicolumn{3}{|c|}{ With trend } \\
\hline & Rho & $P P$ & $A D F$ & Rho & $P P$ & $A D F$ \\
\hline & $2.098^{* *}$ & -0.239 & $5.447^{* * *}$ & 0.789 & $-2.831^{* * *}$ & $6.113^{* * *}$ \\
\hline
\end{tabular}

Notes: ${ }^{a}$ The critical values of Pesaran's CIPS test statistics at the $1 \%(5 \%)[10 \%]$ level are $-2.140(-2.060)[-2.010]$. Symbols $\left.* * *{ }^{*}\right]$ indicate rejection of the null hypothesis of no cointegration at the $1 \%[10 \%]$ significance levels.

${ }^{\mathrm{b}} R h o, P P$, and $A D F$ are the group mean test statistics of Pedroni that tend to $N(0,1)$ under the null hypothesis of no cointegration. Pedroni's test statistics are based on data that have been demeaned. Symbols ${ }^{* * *}\left({ }^{* *}\right)$ indicate rejection of the null hypothesis of no cointegration at the $1 \%(5 \%)$ significance levels.

Table C2. CIPS and Pedroni test statistics for 40 upper-middle-income countries.

(a) CIPS test statistics (based on residuals of MG regression) ${ }^{\mathrm{a}}$

$\begin{array}{lllll} & C A D F(1) & C A D F(2) & C A D F(3) & C A D F(4) \\ \ln C T S & -2.434^{* * *} & -2.160^{* *} & -1.989 & -1.942\end{array}$

(b) Pedroni's test statistics ${ }^{\mathrm{b}}$

\begin{tabular}{|c|c|c|c|c|c|c|}
\hline & \multicolumn{3}{|c|}{ No trend } & \multicolumn{3}{|c|}{ With trend } \\
\hline & Rho & $P P$ & $A D F$ & Rho & $P P$ & $A D F$ \\
\hline $\ln C T S$ & 1.460 & -0.485 & $3.940^{* * *}$ & 0.846 & -1.523 & $6.042^{* * *}$ \\
\hline
\end{tabular}

Notes: ${ }^{a}$ The critical values of Pesaran's CIPS test statistics at the $1 \%(5 \%)[10 \%]$ level are $-2.230(-2.110)[-2.050]$. Symbols ${ }^{* * *}(* *)$ indicate rejection of the null hypothesis of no cointegration at the $1 \%(5 \%)$ significance levels.

${ }^{\mathrm{b}}$ Rho, $P P$, and $A D F$ are the group mean test statistics of Pedroni that tend to $N(0,1)$ under the null hypothesis of no cointegration. Pedroni's test statistics are based on data that he been demeaned. Symbol $^{* * *}$ indicates rejection of the null hypothesis of no cointegration at the $1 \%$ significance level. 
Table C3. CIPS and Pedroni test statistics for 45 lower-middle-income countries.

(a) CIPS test statistics (based on residuals of MG regression) ${ }^{\mathrm{a}}$

\begin{tabular}{lllll}
\hline & $C A D F(1)$ & $C A D F(2)$ & $C A D F(3)$ & $C A D F(4)$ \\
\hline $\ln C T S$ & $-2.275^{* * *}$ & $-2.067^{*}$ & -2.045 & $-2.052^{*}$
\end{tabular}

(b) Pedroni's test statistics ${ }^{\mathrm{b}}$

\begin{tabular}{|c|c|c|c|c|c|c|}
\hline & \multicolumn{3}{|c|}{ No trend } & \multicolumn{3}{|c|}{ With trend } \\
\hline & Rho & $P P$ & $A D F$ & Rho & $P P$ & $A D F$ \\
\hline $\ln C T S$ & $1.847^{*}$ & 0.072 & $4.853^{* * *}$ & 1.237 & -1.188 & $3.948^{* * *}$ \\
\hline
\end{tabular}

Notes: ${ }^{a}$ The critical values of Pesaran's CIPS test statistics at the $1 \%(5 \%)[10 \%]$ level are $-2.230(-2.110)[-2.050]$. Symbols ${ }^{* * *}\left[{ }^{*}\right]$ indicate rejection of the null hypothesis of no cointegration at the $1 \%[10 \%]$ significance levels.

${ }^{\mathrm{b}} R h o, P P$, and $A D F$ are the group mean test statistics of Pedroni that tend to $N(0,1)$ under the null hypothesis of no cointegration. Pedroni's test statistics are based on data that have been demeaned. Symbols ${ }^{* * *}\left[{ }^{*}\right]$ indicate rejection of the null hypothesis of no cointegration at the $1 \%[10 \%]$ significance levels.

Table C4. CIPS and Pedroni test statistics for 30 low-income countries.

(a) CIPS test statistics (based on residuals of MG regression) ${ }^{\mathrm{a}}$

\begin{tabular}{lllll}
\hline & $C A D F(1)$ & $C A D F(2)$ & $C A D F(3)$ & $C A D F(4)$ \\
\hline $\ln C T S$ & $-2.111^{*}$ & -1.819 & -1.844 & -1.664 \\
\hline
\end{tabular}

(b) Pedroni's test statistics ${ }^{\mathrm{b}}$

\begin{tabular}{|c|c|c|c|c|c|c|}
\hline & \multicolumn{3}{|c|}{ No trend } & \multicolumn{3}{|c|}{ With trend } \\
\hline & Rho & $P P$ & $A D F$ & Rho & $P P$ & $A D F$ \\
\hline $\ln C T S$ & -0.301 & -0.300 & 0.326 & 0.464 & -1.005 & 0.146 \\
\hline
\end{tabular}

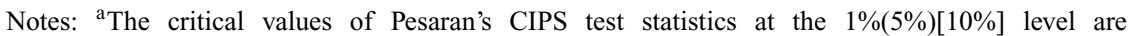
$-2.300(-2.160)[-2.080]$. Symbol [*] indicates rejection of the null hypothesis of no cointegration at the $[10 \%]$ significance level.

${ }^{\mathrm{b}}$ Rho, $P P$, and $A D F$ are the group mean test statistics of Pedroni that tend to $N(0,1)$ under the null hypothesis of no cointegration. Pedroni's test statistics are based on data that have been demeaned. 